DOI: http://doi.org/10.21698/simi.2018.fp14

\title{
REMOVAL OF HEXAVALENT CHROMIUM IONS FROM THE SIMULATED WASTEWATER USING ELECTROCOAGULATION PROCESS
}

\author{
Firas Hashim Kamar ${ }^{1}$, Karim Khalifa Esgair ${ }^{1}$, Baker M. Abod ${ }^{1}$, Aurelia Cristina Nechifor ${ }^{2}$ \\ ${ }^{1}$ Institute of Technology-Baghdad, Middle Technical University, kamarfiras@yahoo.com, \\ karimkhalifa70@yahoo.com, baker_mu@yahoo.com, Iraq \\ ${ }^{2}$ Department of Analytical Chemistry and Environmental Engineering, University Politehnica \\ of Bucharest, 1-7 Gheorghe Polizu, 011061, Bucharest, Romania
}

\begin{abstract}
The removal of hexavalent chromium $\left(\mathrm{Cr}^{+6}\right)$ ions from simulated wastewater was investigated by using batch electrocoagulation. The influence of several variables on the removal process was studied such as a type of electrodes, initial $\mathrm{pH}$, initial concentration of $\mathrm{Cr}^{+6}$ ions, electrolysis time, sodium chloride concentration and current density. The experimental results showed that the removal efficiency of $\mathrm{Cr}^{+6}$ ions was more effective when using iron electrode comparing with the aluminium electrodes. The maximum removal of $\mathrm{Cr}^{+6}$ ions was $96.58 \%$ at $\mathrm{pH} 6.0$, initial ion concentration $40 \mathrm{mg} / \mathrm{L}$, electrolysis time $15 \mathrm{~min}$, sodium chloride concentration 2 $\mathrm{g} / \mathrm{L}$, and the current density $30 \mathrm{~mA} / \mathrm{cm}^{2}$.
\end{abstract}

Keywords: $\mathrm{Cr}^{+6}$ ions, electrocoagulation, heavy metal removal, wastewater

\section{Introduction}

In the last years, the development in industrial led to producing of variant types and a large amount of pollutants discharged directly or indirectly as industrial wastewater. This has affected the surface and groundwater sources (Zhao et al 2018).

In general, the pollutants can be classified into three main groups: biological particles, organic and inorganic. Inorganic pollutants are of interest because they contain heavy metals (Vosoogh et al 2017).

The environmental pollution mainly depends on the presence of heavy metal in the wastewater. Generally heavy metal has density more than 5 g per cubic centimetre. The problem of these elements is the high solubility of their compounds in water, in addition to being carcinogenic and highly toxic. The generality of heavy metal such as chromium, lead cadmium, arsenic and mercury resort to cumulate in living organisms producing different health issues (Azimi et al 2017, Kamar et al 2016). The focus of this study will be on chromium. Hexavalent chromium ions is employed in various industries such as leather tanning, electroplating, pigment, chemical catalyst, printing inks and corrosion inhibitors, which also being present in the wastewater from these industries (Gunatilake 2015, Rehman et al 2015).

$\mathrm{Cr}^{+6}$ ion is a highly poisonous, non-biodegradable and carcinogenic element for the most living organism. Thence $\mathrm{Cr}^{+6}$ ions removal is very important to be done before discharging the wastewater into water bodies (Dermentzis et al 2011).

Commonly, there are various methods employed to remove heavy metal from wastewater such as chemical precipitation, adsorption, ionic exchange, electro- 


\section{INTERNATIONAL SYMPOSIUM "THE ENVIRONMENT AND THE INDUSTRY", SIMI 2018, PROCEEDINGS BOOK}

dialysis, membrane system, bio-sorption, and electro-oxidation. These techniques are employed for effective removal of heavy metal but have some disadvantages, such as generation of other pollutants, operational cost, and being unsuitable for small industries (Chandrasen et al 2013, Kamar et al 2016).

To get over the disadvantage of traditional treatment methods, electrocoagulation technicality has been suggested as an alternative process. This technology has some advantages, it is safe and easy in operation, low cost, with simple equipment installs, reliable and effective, needs short reaction time, certain efficient, generate less sludge, uses less chemicals, and is effective for a wide range of contaminants. The only one disadvantage of this technology is the need of replacing the sacrificial electrodes (Vlachou et al 2013, Beyazit et al 2014).

Electrocoagulation has been exhibit efficient results in various wastewater treatment applications, such as textile wastewater, tannery wastewater, oil-water emulsions, purification of drink water, and removal of heavy metal ions, dairy wastewater and slaughterhouse wastewater (Khalaf et al 2016).

This work is aimed to study the effect of operating variables which include the type of electrode, initial $\mathrm{pH}$, initial $\mathrm{Cr}^{+6}$ concentration, contact time, wastewater conductivity, current density on the removal efficiency of $\mathrm{Cr}^{+6}$ from simulated wastewater to determine the best-operating conditions.

\section{Materials and Methods}

Electrocoagulation experiments

A glass electrocoagulation reactor was used to conduct the experiments. The volume of the reactor was $500 \mathrm{~mL}$. Each pair of iron and aluminium reactor electrodes plates were used in parallel, vertically positioned, having a rectangular shape (dimensions $6.0 \mathrm{~cm} \times 4.0 \mathrm{~cm} \times 1 \mathrm{~mm}$ ). The interspace between two electrodes was $10 \mathrm{~mm}$. The current supply to the process from a digital power source (PS-305D, Dazheng, China) to attain required values of current densities applied in the experiments. Electrolysis time was 5, 10, 15, 20, 25 and 30 minutes.

All electrodes were cleaned after each experiment, the precipitates of metal hydroxide and other impurities being removed from electrodes by immersion in 0.01 $\mathrm{M}$ of hydrochloric acid for three minute, and abundantly wash by water, then weighted after air drying. The electrodes must be replaced if loss about ten percent from its weight.

Prepared wastewater

Dried potassium dichromate was employed to prepare synthetic wastewater with $\mathrm{Cr}^{+6}$ ions concentration of $1000 \mathrm{mg} / \mathrm{L}$ by dissolved $2.82 \mathrm{~g}$ of dried potassium dichromate in the one-litter deionized water. Electrical magnetic stirrer was used to mix the potassium dichromate with deionized water. The initial concentration $\left(\mathrm{C}_{0}\right)$ varied between 20 and $100 \mathrm{mg} / \mathrm{L}$.A $0.1 \mathrm{M} \mathrm{H}_{2} \mathrm{SO}_{4}$ or $0.1 \mathrm{M} \mathrm{NaOH}$ was used to adjust $\mathrm{pH}$ value of simulated wastewater between 2.0 and 12.0 and concentration of $\mathrm{NaCl}$ from 0 to $4.0 \mathrm{~g} / \mathrm{L}$ was used to obtain a varied conductivity. To study the influence of any one of above variable on the removal of $\mathrm{Cr}^{+6}$ ion, that variable has been varied gradually while keeping the other variables constant to obtained the maximum removal percent of chromium by electrocoagulation process. 


\section{INTERNATIONAL SYMPOSIUM "THE ENVIRONMENT AND THE INDUSTRY", SIMI 2018, PROCEEDINGS BOOK}

Analytical methods

Ultraviolet visible spectrophotometer (Model 6310, Jenway Co., UK) was used to measure the $\mathrm{Cr}^{+6}$ ions concentration in wastewater at $540 \mathrm{~nm}$ wavelength with diphenyl carbazide.

In the end of each experiment, the concentration of $\mathrm{Cr}^{+6}$ ions in solution at equilibrium was measured (filtered sample).

The removal efficiency of ions ( $\mathrm{R} \%$ ) due to electrocoagulation process was calculated according to the following equation:

$$
R \%=\frac{C_{0}-C_{e}}{C_{0}} \times 100
$$

where:

$\mathrm{C}_{o}=$ is the $\mathrm{Cr}^{+6}$ ions concentration in the wastewater before experiment;

$\mathrm{Ce}_{\mathrm{e}}=$ is the concentration of $\mathrm{Cr}^{+6}$ ions at equilibrium.

Digital multi range ammeter and voltmeter was used to measure the current and voltage supply to the electrocoagulation reactor.

\section{Results and Discussions}

Effect of the electrode material

The influence of the various electrode material pairs on the removal efficiency of the $\mathrm{Cr}^{+6}$ ions using electrocoagulation method was studied by making all variables constant and changes the type of electrode material only (see Figure 1). The pairs of electrodes were coordinated as anode/ cathode $\mathrm{Al} / \mathrm{Al}$, and $\mathrm{Fe} / \mathrm{Fe}$ to carry out the experiments. Laboratory experiments demonstrated that the pair of electrodes $\mathrm{Fe} / \mathrm{Fe}$ has given the highest percentage removal of $\mathrm{Cr}^{+6}$ ions, reaching $58 \%$, while the pair of electrodes $\mathrm{Al} / \mathrm{Al}$ reaches $49 \%$ for the same conditions. The explanation for that is the number of anions that are generated in the electrocoagulation with $\mathrm{Fe} / \mathrm{Fe}$ is much higher than the anions generated with $\mathrm{Al} / \mathrm{Al}$, according to Faraday's first law for electrolysis. Therefore, firstly that the amount of metal hydroxide generated, density and concentration of hydroxide groups flocs in the electrocoagulation cell when using $\mathrm{Fe}-\mathrm{Fe}$ are higher than when using $\mathrm{Al} / \mathrm{Al}$, which leads to the removal of $\mathrm{Cr}^{+6}$ ions from wastewater through adsorption of $\mathrm{Cr}^{+6}$ ions by a complex reaction on the surface with a hydroxyl group.

Secondly, the electrolysis of iron leads to the formation of $\mathrm{Fe}^{+2}$, which in turn oxidize to $\mathrm{Fe}^{+3}$ due to the presence of oxygen dissolved in the electrocoagulation cell, which helps to reduce hexavalent chromium to $\mathrm{Cr}^{+3}$ ions, which precipitates, therefore the $\mathrm{Cr}^{+6}$ ions can be removed by surface reactions and precipitation reactions.

For these reasons the pair of electrodes $\mathrm{Fe} / \mathrm{Fe}$ was selected in all subsequent experiments. Lu et al. study also the removal of $\mathrm{Cr}^{+6}$ ions from aqueous solution using electrocoagulation and found that the best electrode material pairs are iron ( $\mathrm{Lu}$ et al 2016). 


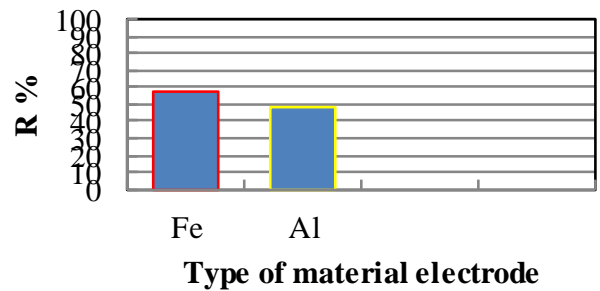

Figure 1. The effect of type of electrode material on the removal efficiency of $\mathrm{Cr}^{+6}$ ions; $\mathrm{t}=30 \mathrm{~min}$, current density $=20 \mathrm{~mA} / \mathrm{cm}^{2}, \mathrm{NaCl}=1 \mathrm{~g} / \mathrm{L}, \mathrm{Co}_{\mathrm{O}}=40 \mathrm{mg}, \mathrm{pH}=4$.

\section{Effect of initial $\mathrm{pH}$}

Figure 2 illustrates the influence of the primary $\mathrm{pH}$ of simulated wastewater on the removal efficiency of $\mathrm{Cr}^{+6}$ ions. This figure demonstrates the removal of this ions is increased with increases the initial $\mathrm{pH}$ of the wastewater, reaching $78 \%$ as its highest value at $\mathrm{pH}=6$. The $\mathrm{Cr}^{+6}$ ions removal percentage was decreases slightly with an acidity of up to $74 \%$ at $\mathrm{pH} 8$. After that, the removal efficiency of $\mathrm{Cr}^{+6}$ ions was a fast decreased with the initial $\mathrm{pH}$ increase.

In general, there are two mechanisms for removal of the $\mathrm{Cr}^{+6}$ ions, the first is the precipitation and co-precipitation and the second is the adsorption, but when the mechanisms precipitation and co-precipitation are weak, that adsorption will be dominant in this process. From the above, we will be chosen the initial pH 6 for subsequent experiments. Arroyo et al 2009 found the maximum removal of $\mathrm{Cr}+6$ ions from aqueous solution using electrocoagulation at $\mathrm{pH} 6.0$.

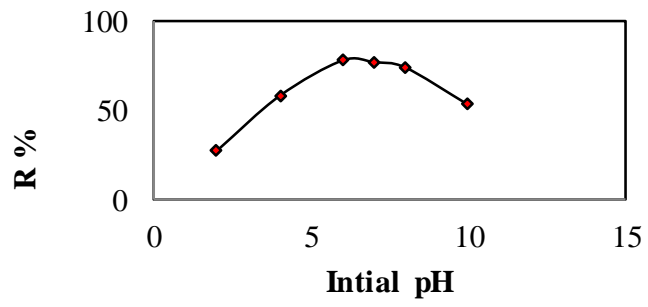

Figure 2. Effect of initial $\mathrm{pH}$ on the removal efficiency of $\mathrm{Cr}^{+6}$ ions; $\mathrm{t}=30 \mathrm{~min}$, current density $=20 \mathrm{~mA} / \mathrm{cm}^{2}, \mathrm{NaCl}=1 \mathrm{~g} / \mathrm{L}, \mathrm{Co}_{0}=40 \mathrm{mg}$.

Effect of initial concentration for $\mathrm{Cr}^{+6}$ ions

The influence of the initial concentration of $\mathrm{Cr}^{+6}$ ions between 20 and $100 \mathrm{mg} / \mathrm{L}$ on the removal efficiency was studied. Experimental data denote that the removal efficiency of $\mathrm{Cr}^{+6}$ ions was decreasing with increasing the initial concentration of it as shown in figure 3 . The removal efficiency gradually decreased from $78 \%$ to $49 \%$ when initial concentration increased from 40 to $100 \mathrm{mg} / \mathrm{L}$. This is due to the fact when the $\mathrm{Cr}^{+6}$ ions concentration increase, the quantity of coagulant produced from 


\section{INTERNATIONAL SYMPOSIUM "THE ENVIRONMENT AND THE INDUSTRY", SIMI 2018, PROCEEDINGS BOOK}

electrolysis of anodic electrode is constant when all variable are constant, so with increasing the $\mathrm{Cr}^{+6}$ ions concentration, the quantity of coagulant turn into very low compared with the $\mathrm{Cr}^{+6}$ ions, subsequently deceasing the removal efficiency.

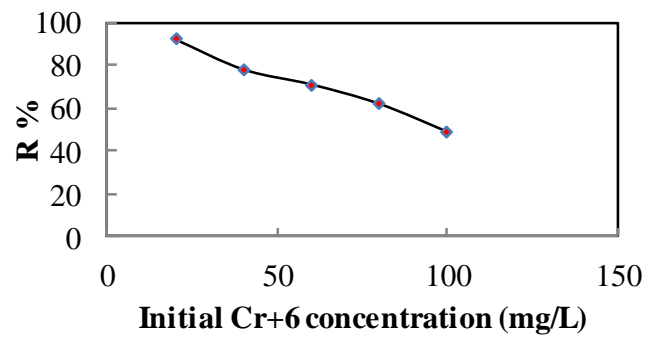

Figure 3. Effect of initial concentration for $\mathrm{Cr}^{+6}$ ions on the removal efficiency of $\mathrm{Cr}^{+6}$ ions; $\mathrm{t}=30 \mathrm{~min}$, current density $=20 \mathrm{~mA} / \mathrm{cm} 2, \mathrm{NaCl}=1 \mathrm{~g} / \mathrm{L}, \mathrm{pH}=6$.

Effect of electrocoagulation time

Removal of $\mathrm{Cr}^{+6}$ ions was investigated in electrocoagulation reactor at electrolysis time between 5 and $30 \mathrm{~min}$ and figure 4 shows that. This figure shows that removal of this ions increase with increasing of electrolysis time to reach $78 \%$ as a maximum value at 15 min of electrolysis time and it rests approximately fixed with despite increasing the electrolysis time. Therefore, we chose $15 \mathrm{~min}$ as the best electrolysis time for all experiments (similar to Dubrawski et al 2015)

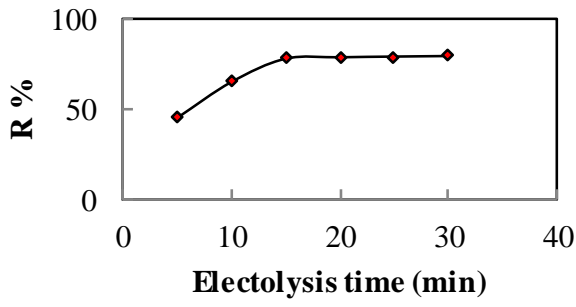

Figure 4. Effect of electrolysis time on the removal efficiency of $\mathrm{Cr}^{+6}$ ions; $\mathrm{pH}=6$, current density $=20 \mathrm{~mA} / \mathrm{cm}^{2}, \mathrm{NaCl}=1 \mathrm{~g} / \mathrm{l}, \mathrm{Co}=40 \mathrm{mg}$.

\section{Effect of conductivity}

The influence of conductivity for simulated wastewater on the removal of $\mathrm{Cr}^{+6}$ ions was studied by using $\mathrm{NaCl}$ concentration between 0 and $4 \mathrm{~g} / \mathrm{L}$ as shown in figure 5 . $\mathrm{Cr}^{+6}$ removal increased quickly with increasing the conductivity of simulated wastewater, reaching the highest value of $85.2 \%$ when that the $\mathrm{NaCl}$ concentration was $2 \mathrm{~g} / \mathrm{L}$. Since we desired the highest removal efficiency and minimum salting of the simulated solution after electrocoagulation, therefore we considered the best conductivity of wastewater corresponding to $2 \mathrm{~g} / \mathrm{l}$ of $\mathrm{NaCl}$, which was used for the subsequent experiments. 


\section{INTERNATIONAL SYMPOSIUM "THE ENVIRONMENT AND THE INDUSTRY", SIMI 2018, PROCEEDINGS BOOK}

This experimental results may be interpreted as a follow: the conductivity of the electrolyte increases when the concentration of $\mathrm{NaCl}$ increases and the passivation removed by the anions $\mathrm{Cl}^{-}$were increases also, therefore increases the electrolysis rate of a sacrificial anode by the participation of $\mathrm{Cl}^{-}$in the reaction of metal electrolysis or by the incorporation of $\mathrm{Cl}^{-}$in the oxide film (El-Taweel et al 2015).

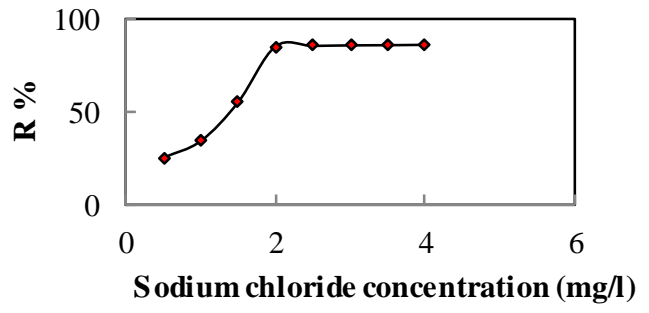

Figure 5. Effect of wastewater conductivity on the removal efficiency of $\mathrm{Cr}^{+6}$ ions; $\mathrm{t}=15 \mathrm{~min}$, current density $=20 \mathrm{~mA} / \mathrm{cm}^{2}, \mathrm{Co}_{\mathrm{O}}=40 \mathrm{mg}, \mathrm{pH}=6$.

\section{Effect of current density}

One of the main parameters to control of electrocoagulation technique is the current density. It is also an important variable for the economy of energy and consumption of the electrode, because it is determining the coagulant production rate, as well as the hydrogen production which influences on the growth rate and bulk of flocs.

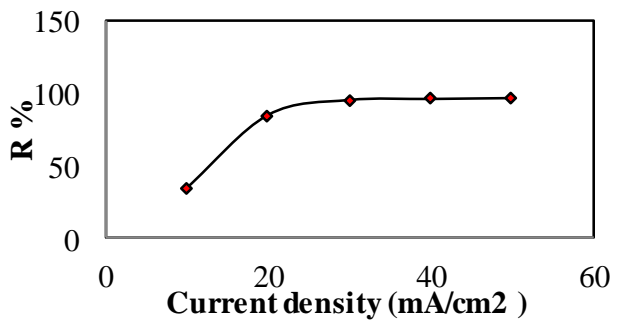

Figure 6. Effect of current density on the removal efficiency of $\mathrm{Cr}^{+6}$ ions; $\mathrm{t}=15 \mathrm{~min}$, $\mathrm{NaCl}=2 \mathrm{~g} / \mathrm{L}, \mathrm{Co}_{\mathrm{O}}=40 \mathrm{mg}, \mathrm{pH}=6$.

Figure 6 show effects of several current densities used between 10 and $50 \mathrm{~mA} / \mathrm{cm}^{2}$ on the removal of $\mathrm{Cr}^{+6}$ ions by electrocoagulation. The results obtained from experiments were explained by the increase of the current density from 10 to 20 $\mathrm{mA} / \mathrm{cm}^{2}$ was caused to increase the ions removal from $35.4 \%$ to $85.2 \%$, whereas the increase from 20 to $30 \mathrm{~mA} / \mathrm{cm}^{2}$ was caused an in increase the $\mathrm{Cr}^{+6}$ ions removal from $85.2 \%$ to $95.58 \%$. While the increasing of the current density from 30 to 40 $\mathrm{mA} / \mathrm{cm}^{2}$ was given an insignificant increase in the ions removal (from $95.5 \%$ to $96.2 \%$ ), accordingly, $30 \mathrm{~mA} / \mathrm{cm}^{2}$ was selected as a best current density. The reason 


\section{INTERNATIONAL SYMPOSIUM "THE ENVIRONMENT AND THE INDUSTRY", SIMI 2018, PROCEEDINGS BOOK}

for this is due to the electrical energy consumption was concerning with the square rate of the current density (Lee \& Gagnon 2016).

\section{Conclusions}

The present study shows that the electrocoagulation is an effective technique for removal of $\mathrm{Cr}^{+6}$ ions from industrial wastewater. The efficiency of this process was influenced major by the following variables: initial $\mathrm{pH}$, initial concentration of $\mathrm{Cr}^{+6}$ ions, electrolysis time, simulated wastewater conductivity as well as current density. The removal process efficiency was increased with increase of $\mathrm{pH}$ value up to 6.0; also it's increased with increasing other variables such as electrolysis time, wastewater conductivity, and current density, while it's decreased with increasing the initial concentration of hexavalent chromium. The maximum removal efficiency of $\mathrm{Cr}^{+6}$ ions, up to $96.58 \%$ was obtained for $\mathrm{pH}=6.0$, initial concentration of chromium ions $40 \mathrm{mg} / \mathrm{L}$, electrolysis time $15 \mathrm{~min}$, salt content of simulated wastewater $2 \mathrm{~g} \mathrm{NaCl} / \mathrm{L}$, and current density $30 \mathrm{~mA} / \mathrm{cm}^{2}$.

\section{References}

Azimi, A, Azari, A, Rezakazemi, M \& Ansarpour, M 2017, 'Removal of Heavy Metals from Industrial Wastewaters: A Review’, ChemBioEng Reviews, vol. 4, no. 1, pp. 37-59.

Arroyo, MG, Perez-Herranz, V, Montanes, MT, Garcia-Anton, J \& Guinon, JL 2009, 'Effect of $\mathrm{pH}$ and chloride concentration on the removal of $\mathrm{Cr}^{6}{ }^{6}$ in a batchelectrocoagulation reactor', Journal of Hazard Material, vol. 169, pp. 1127-1133.

Beyazit, N, 2014, 'Copper (II), Chromium (VI) and Nickel (II) Removal from Metal Plating Effluent by Electrocoagulation', International Journal of Electrochemistry Science, vol. 9, pp. 4315-4330.

Chandrasen, F, Rajemahadik, SV, Kulkarni, H \& Kulkarni, GS 2013, 'Efficient Removal of Heavy Metals from Electroplating Wastewater using Electrocoagulation', International Journal of Scientific and Research Publications, vol. 3, no. 10, pp.1-5.

Dermentzis, K, Christoforidis, A \& Valsamidou, E 2011, 'Removal of nickel, copper, zinc and chromium from synthetic and industrial wastewater by electrocoagulation', International Journal of Electrochemistry Science, vol. 1, no 5, pp. 697-708.

Dubrawski, KL, van Genuchten, CM, Delaire, C, Amrose, SE, Gadgil, AJ \& Mohseni, M 2015, 'Production and transformation of mixed-valent nanoparticles generated by $\mathrm{Fe}(0)$ electrocoagulation’, Environmental Science and Technology, vol. 49, pp. 2171-2179.

El-Taweel, YA, Nassef, Ehssan, MI \& Doaa Sayed, E 2015, 'Removal of Cr(VI) ions from waste water by electrocoagulation using iron electrode', Egyptian Journal of Petroleum, vol. 24, pp.183-192.

Gunatilake, SK 2015, 'Methods of Removing Heavy Metals from Industrial Wastewater', Journal of Multidisciplinary Engineering Science Studies, vol. 1, no. 1, pp.1309-1318.

Khalaf, AM, Mubarak, AA \& Nosier, SA 2016, 'Removal of Cr (VI) by Electrocoagulation Using Vertical and Horizontal Rough Cylinder Anodes', International Journal of Electrochemistry Science, vol. 11, pp. 1601-1610. 


\section{INTERNATIONAL SYMPOSIUM "THE ENVIRONMENT AND THE INDUSTRY", SIMI 2018, PROCEEDINGS BOOK}

Kamar, FH, Mohammed, AA, Faisal, AAH, Nechifor, AC \& Nechifor, G 2016, 'Biosorption of Lead, Copper and Cadmium Ions from Industrial Wastewater Using Fluidized Bed of Dry Cabbage Leaves’, Revista de Chimie, vol. 67, no. 6, pp. 1039-1046.

Lu, J, Wang, ZR, Yu-Ling Liu, YL, Qing \& Tang, Q 2016, 'Removal of Cr ions from aqueous solution using batch electrocoagulation: Cr removal mechanism and utilization rate of in situ generated metal ions', Process Safety and Environmental Protection, vol. 104, pp. 436-443.

Lee, SY \& Gagnon, GA 2016, 'Growth and structure of flocs following electrocoagulation', Separation and Purification Technolology, vol. 163, pp. 162-168.

Rehman, A, Kim, M, Reverberi, A \& Fabiano, B 2015, 'Operational Parameter Influence on Heavy Metal Removal from Metal Plating Wastewater by Electrocoagulation Process', Chemical Engineering Transactions, vol. 43, pp. 2251-2256.

Vosoogh, A, Baghvand, A \& Saghakhaneh, H 2017, 'Removal of heavy metals and hardness from groundwater via electro-coagulation method', Pollution, vol. 3, no. 2, pp. 213-224

Vlachou, M, Hahladais, J \& Gidarakos, E, 2013 'Effect of Various Parameter in Removing $\mathrm{Cr}$ and Ni From Model Wastewater by Using Electrocoagulation', Global NEST Journal, vol. 15, no. 4, pp. 494-503.

Zhao, Y, Kang, D, Chen, Z, Zhan, J \& Wu, X 2018, 'Removal of Chromium Using Electrochemical Approaches: A Review', International Journal of Electrochemistry Science, vol. 13, pp. 1250-1259. 